\title{
A Case of Spinal Thoracic Empyema Following Epidural Injection
}

\author{
Epidural Enjeksiyon Sonrası Gelișen Spinal Torakal Ampiyem Olgusu
}

\begin{abstract}
.
\section{ABSTRACT}

Spinal thoracic empyema is a complicated, important spinal pathology that is seen sporadically or following surgery or trauma. In this report, we aimed to present a case with spinal thoracic empyema following epidural injection and to draw attention to this rare etiologic cause.

Keywords: Epidural injection, myelopathy, thoracic empyema

\section{Introduction}

In recent years, different complications due to widely applied spinal epidural injections can be seen. In this report, we present a thoracic empyema case with paraparesis and a previous history of spinal epidural injection.
\end{abstract}

\section{öz}

Spinal torakal ampiyem cerrahiye, travmaya bağlı ya da sporadik olarak ortaya çıkan, komplike, önemli bir spinal patolojidir. Bu yazıda epidural enjeksiyon sonrası gelișen spinal torakal ampiyem olgusunu sunmak ve bu nadir etiyolojik nedene dikkat çekmek istedik.

Anahtar Kelimeler: Epidural enjeksiyon, miyelopati, torakal ampiyem

\section{Case Report}

A 46-year-old male patient presented with complaints of numbness and weakness of the legs, and urinary incontinence. The patient stated that low back pain and numbness started about 3 months ago and that his complaints increased over the last 20 days. From the patient's medical history, it was learned that he was hospitalized due to neck pain for seven days in an algology service of another hospital approximately one year ago and underwent spinal epidural injection. The patient said that he did not benefit from this treatment, which was repeated once in every 15 days for a total of 4 times. His past medical history revealed that he had kidney stones and hypertension, and he had sequelae in his right lower extremity due to traffic accident at the age of 12 years. His family history was unremarkable except spinal muscular atrophy in the medical history of his brother. There were night sweats and about $10 \mathrm{~kg}$ of involuntary weight loss in the last 3 months. Neurological examination revealed $3 / 5$ motor strength in bilateral lower extremity, positive Babinski reflex on the left, areflexia on the lower extremities and sphincter defect. Routine laboratory tests White Blood Cell=9.53, Hemoglobin Hgb=14.8, C-reaktif protein $=0.306$, Sedimentation $=9 \mathrm{~mm} / \mathrm{h}$ ) were within normal limits. Cervical spinal magnetic resonance imaging (MRI) revealed diffuse hyperintensity consistent with diffuse edema in the spinal cord and $8 \times 5$ $\mathrm{mm}$ wide subdural collections starting from the seventh cervical vertebra level and showing caudal extension, more prominent posteriorly. These findings were found to be consistent with subdural empyema. Thoracic spinal MRI revealed T2W hyperintense, T1W mild hypointense diffuse edematous signal changes in the central dorsal spinal cord, involving gray matter with mild expansion. Contrast-enhanced sections revealed arachnoidal and dural diffuse and prominent contrast enhancement. Appearance consistent with empyema was observed between T2-9 vertebra levels (Figure 1). In the cerebrospinal fluid (CSF) examination, glucose was $33 \mathrm{mg} / \mathrm{dL}$ (concomitant blood glucose $=121 \mathrm{mg} / \mathrm{dL}$ ), protein was $562.3 \mathrm{mg} / \mathrm{dL}$, and 40 leukocytes (60-70\% mononuclear leukocytes $(\mathrm{MNL})$ were detected in the cell count. Pandy was $(++++)$ positive, acidfast bacilli and tuberculosis (TBC) Polymerase chain reaction (PCR) were negative. Since TBC could not be excluded with CSF findings, anti-TBC treatment was initiated. In the surgery performed for thoracic empyema, the arachnoid plan was lost, clear fluid was obtained by puncture from the thoracic region, cavitary areas were observed under the tissue and sampling was performed from calcific tissues. Dexamethasone 


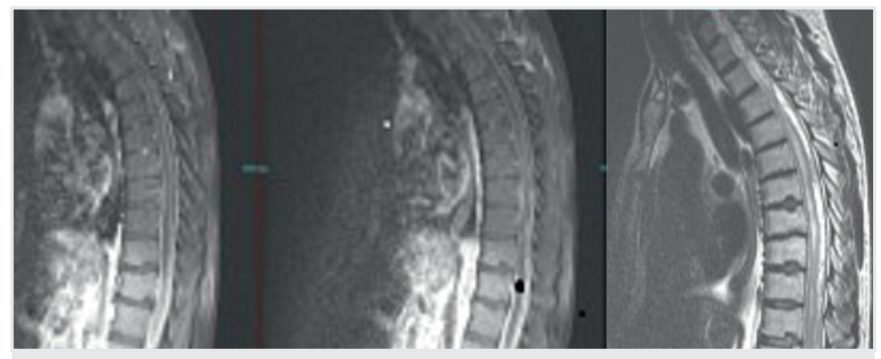

Figure 1. T1- and T2-weighted thoracic spinal magnetic resonance images of the patient

treatment was added to anti-TBC treatment and patient was followed up. One month later, the lower extremity muscle strength of the patient improved to $4 / 5$, however, urinary and fecal incontinence persisted.

In the late-term pathology report, it was noted that pre-operative CSF sample did not have any atypical cells and that small number of mature-looking lymphocytes, activated lymphocytes and macrophages were observed with PAP and Giemsa staining.

In the histochemical examinations of the specimen obtained during the surgery, no bacillary microorganism was observed with EZN staining and no fungal organism was observed with PAS staining. Necrotizing granulomatous inflammation was detected in the sample obtained from the intramedullary area. Lymphocytes and polymorphonuclear leukocytes were observed in the sample from intramedullary spinal fluid.

As the patient could not be reached in the follow-up, no information could be obtained about his final condition. The informed consent was obtained from the patient.

\section{Discussion}

Spinal epidural empyema is an insidious clinical condition that can be treated by early diagnosis and intervention, but its diagnosis is often delayed. Typical clinical findings include localized back pain, fever and neurological deficits. While empyema causes myelopathy due to pressure on the spinal cord, this situation may lead to motor weakness that can be even permanent $(1,2)$. Difficulty in diagnosis and delay in treatment of patients with atypical clinical findings lead to increased morbidity and mortality (1).

Hematogenous spread from the upper respiratory tract or a dental infection has been described as possible etiologies in some cases, but it has also been identified as a local complication of vertebral osteomyelitis (3). In the literature, although it is defined as iatrogenic after spinal epidural catheterization, spinal extradural block or interventions for discopathy, sporadic cases are also reported $(4,5)$. In our case, we thought that spinal epidural injection performed for neck pain had a role in etiology. While spinal epidural empyema usually occurs with Staphylococcus aureus, Mycobacterium tuberculosis and Brucellosis are other common microorganisms (2). Our patient was negative for Brucella serology and PCR, and mycobacterial culture.

MRI is diagnostic in most cases. The homogenous contrast enhancement caused by granulomatous tissue in the MRI is seen as a mass or as a contrast-enhancing inflammatory tissue (6). In our case, MRI revealed diffuse hyperintensity consistent with diffuse edema in the spinal cord and appearance that might be significant in terms of empyema around the cord between T2-9 vertebra levels accompanied by contrast enhancement.

Lumbar puncture is also a guiding for the detection of the agent. Low CSF glucose level compared to the concomitant blood glucose level was thought to be in favor TBC. However, regarding negative mycobacteria culture and PCR studies along with a previous history of spinal epidural injection, decreased glucose level was thought to be secondary to localized infection.

While surgical drainage and decompression with concomitant antibiotic therapy is required in most of the cases, antibiotic therapy may be sufficient in some well-selected cases. Our case also benefited from surgery and empiric antibiotics for possible bacterial microorganisms and TBC.

\section{Conclusion}

In case of affected spinal cord and the surrounding tissue in spinal imaging of patients admitting with paraparesis, questioning epidural injection in the history is important in the differential diagnosis and treatment.

Informed Consent: The informed consent was obtained from the patient.

Peer-review: Externally peer-reviewed.

Author Contributions: Concept - U.E.; Design - F.M.; Supervision - U.E.; Resources - F.M.; Materials - V.A.; Data Collection and/or Processing Y.K.; Analysis and/ or Interpretation - O.Y.; Literature Search - F.M., E.L.; Writing Manuscript - F.M.; Critical Review - U.E.

Conflict of Interest: No conflict of interest was declared by the authors.

Financial Disclosure: The authors stated that they did not receive financial support for this study.

\section{References}

1. Nussbaum ES, Rigamonti D. Spinal epidural abscess: A report of 40 cases and review. Surgical Neurology 1992; 38: 225-31.

2. Karaarslan G, Akalın Y. Iatrogenic reactive inflamantation with thick membrane mimicking spinal epidural abcess after lumbar disc surgery: A case report and literature review. Türk Nöroșirurji Dergisi 2011; 21: 34-8.

3. Baker AS, Ojemann RG, Swartz MN, Richardson EP. Spinal epidural abscess. $N$ Engl J Med 1975; 293: 463-8.

4. Sarubbi FA, Vasquez JE. Spinal epidural abscess associated with the use of temporary epidural catheters: report of two cases and review. Clinical Infectious Diseases 1997; 25: 1155-8.

5. John F, Ferguson JF, Kirsch WM. Epidural empyema following thoracic extradural block case reports and technıcal notes. J Neurosurg 1974; 41: 7624 .

6. Köksal V, Güçer H. Thoracic spinal epidural empyema presentation progressive paraparesis in a healthy individual and surgical treatment: Case report. Türk Nöroşirürji Dergisi 2011; 21: 60-3. 